Glanc J., Osiewacz P., The second-generation informational problem in the financial markets, 0,Ekonomia i Prawo. Economics and Law”, Polszakiewicz B., Boehlke J. (ed.), Vol. 14, No. 3/2015, pp. 341-350. DOI: http://dx.doi.org/10.12775/EiP.2015.022.

\author{
JADWIGA GLANC*, PIOTR OSIEWACZ ${ }^{* *}$
}

\title{
THE SECOND-GENERATION INFORMATIONAL PROBLEM IN THE FINANCIAL MARKETS
}

\author{
SUMMARY
}

This article deals with a new informational problem in the financial markets and shows how increasing reliance on standardized sources of information (rating agencies, financial media, journals etc.) can potentially lead to crises. It examines the way in which the problem of information on the markets has changed partly as a result of current legal frames on disclosure and information obligation. Furthermore, it links the phenomenon of increasing reliance on information sources to the current problems and deficiencies of investment decisions. The analysis examines the standard legal responses of the financial markets in order to search for a viable solution to the problem of market deficiencies in this regard. Attention is drawn to a serious flaw in the financial markets and to an increasing shift of power towards private information-supplying entities, all of which could lead to disruptions of financial stability in the future.

Keywords: financial markets; financial crises; sources of market information; financial media

JEL Classification: G01; G14; G15; G28; G65

"Jadwiga Glanc, Jagiellonian University, Faculty of Law, Department of Commercial Law, ul. Olszewskiego 2, 31-007 Kraków, Poland, phone: +48 126631 385, e-mail: jadwiga.glanc@ uj.edu.pl (corresponding author).

* Piotr Osiewacz, Jagiellonian University, Faculty of Law, Department of Commercial Law, ul. Olszewskiego 2, 31-007 Kraków, Poland, phone: +48 503102 644, e-mail: piotrosiewacz@ gmail.com. 


\section{INTRODUCTION}

Information is a key issue in the financial markets. From the investor's standpoint information is arguably the most important factor in the act of investing. The investor's access to information is also crucial from the standpoint of the regulators, as it ensures that the market is effective. Another consideration is that a lack of information or the existence of misleading information are factors that can eventually lead to the disruption of financial stability. Recent financial crises are good examples of this kind of situation. This is why a close scrutiny of problems in the information zone is so crucial. And it would appear that a new threat is lurking in the ever-growing combination of globalization, deficiencies in the strategies of investors (e.g. speculation, noise trading and herding) and the increasingly strong position of sources of market information ${ }^{1}$. In particular, the latter factor is of pivotal significance: though worrying, the growing influence of information sources on the creation of reality in the financial markets generally goes unquestioned.

There is a firm link between these three issues, because globalization and deficiencies in investors' strategies have created a unique window of opportunity for the dissemination and reception of information, which further boosts the growing capacity of existing sources of information to influence the markets. Their impact is changing the way in which the problem of information on the markets is perceived and raises the question of the extent to which private entities should influence trading. Moreover, it opens a field for deliberations on what kind of regulation could be used in order to preclude irregularities in the dissemination of information and thus forestall any potential manipulation of the markets.

The aim of this article is to take a general look at how these issues are connected and to consider possible solutions that might counter their adverse effects. This article is not an analysis of any particular legal system, but rather aims to be a general review of problems and methods of dealing with them.

\section{INFORMATION AND INFORMATION SUPPLIERS}

Information is at the very centre of the markets and a lot of scholarly works have been written on the importance of information, insider trad-

${ }^{1}$ If we look back closely at what happened during previous financial crises, there are three factors that would seem to be inherent in a situation of grave concern in the markets: globalization, herding and the problem of information about the market. 
ing issues or, recently, on the rating agencies and their position. The issue of who is delivering news and how is gaining momentum. Standardized news items are delivered by rating agencies, news agencies and other financial and economic media. Undeniably, these sources differ from each other to a certain extent. Their manner of operation and their impact on the markets vary. However, the fact that they provide a basis for investment decisions justifies their being grouped and described together.

At one end, we have rating agencies which supply investors with ratings. Investors rely on them in order to make more informed decisions about given investments. It is now recognized that rating agencies can generate the "selffulfilling prophecy" effect ${ }^{2}$. At the other end, we have the financial media, providing more or less general financial news. Journals and other media had previously been thought to have a minor or non-existent impact on the markets $^{3}$. It was believed that the general media could not have any real impact on the markets in the long run. In recent years, however, this view has been subjected to further scrutiny and has been contested ${ }^{4}$. Recent studies ${ }^{5}$ show that journals (and media in general) influence markets and can boost crises ${ }^{6}$. Moreover, even general information and opinions of influential newspapers may have informative value for the markets in periods of market unpredictability $^{7}$. The more investors pay attention to one particular source, the greater the effect ${ }^{8}$. And, of course, in such a situation it is only too easy for the "selffulfilling prophecy" effect to occur ${ }^{9}$. These new views on information suppliers and their influence raises the question of the approach that ought to be taken towards them.

2 A. Grzelak, Wybrane zagadnienia obecnego kryzysu ekonomicznego, Prace Naukowe Uniwersytetu Ekonomicznego we Wrocławiu. Ekonomia, Vol. 113/2010, p. 48.

3 J. Kleinnijenhuis, F. Schultz, D. Oegema, W. van Atteveldt, Financial news and market panics in the age of high-frequency sentiment trading algorithms, "Journalism", Vol. 14, No. 2/2013, pp. 275-276; R. Casarin, F. Squazzoni, Being on the Field When the Game Is Still Under Way. The Financial Press and Stock Markets in Times of Crisis, "PLoS ONE", Vol. 8, No. 7/2013, pp. 1-14.

${ }^{4}$ For some interesting remarks on the position of the media see: P.A. Thompson, Invested interests? Reflexivity, representation and reporting in financial markets, "Journalism", Vol. 14, No. 2/2013, pp. 208-227; R. Casarin, F. Squazzoni, op. cit., p. 12.

${ }^{5}$ J. Kleinnijenhuis, F. Schultz, D. Oegema, W. van Atteveldt, op. cit., pp. 280-287.

${ }^{6}$ Ibidem, p. 287.

7 R. Casarin, F. Squazzoni, op. cit., p. 12.

${ }^{8}$ P.A. Thompson, Market Manipulation? Applying the Propaganda Model to Financial Media Reporting, "Westminster Papers in Communication and Culture", Vol. 6, No. 2/2009, p. 86.

${ }^{9}$ Ibidem. 


\section{METHODOLOGY}

The important point about the position and power of the information suppliers is that they are closely connected with other current problems of the market, as to some extent they are interdependent and an escalation in one area can lead to aggravation in others. It is therefore important to examine how all this ties in with other existing issues. Potentially, the problem could lead to market instability on a global scale. For this reason the informational zone problems should be discussed and links with other issues should be examined. A comparison of existing deficiencies in investment strategies or behaviours and problems in the informational zone will lay bare any vulnerabilities and will also answer the question as to whether and to what extent the consideration of regulation and legal means in order to counter the problem is justified.

\section{THE INFORMATIONAL PROBLEM}

The informational problem which will be discussed is somewhat different from the famous "asymmetry of information" problem - the "first generation problem" - though it is closely connected with it and, indeed, takes its origin from it. Generally speaking, the asymmetry of the information problem comes down to information discrepancies and conflicting incentives between entrepreneurs on the one hand and savers on the other - something that can cause the markets to be ineffective ${ }^{10}$. One would have thought that after so many years of discussing the "problem of information" and the asymmetry of information the situation would have improved, given the multiple regulations aimed at diminishing the problem. However, this is not quite the case. Moreover, it would seem that the second problem has actually evolved in this environment. Given the multifarious regulations on informational obligation and disclosure - together with voluntary disclosures - investors increasingly tend to rely on standardized sources of information, which are the information-zone equivalent of "fast food" or "drive-through". This is because there is too much information and also because it is often very ambiguous, which leads to a situation in which investors prefer either to read a magazine in order to find out what to think about a given situation or to rely on the

10 P.M. Healy, K.G. Palepu, Information asymmetry, corporate disclosure, and the capital markets: A review of the empirical disclosure literature, "Journal of Accounting and Economics", Vol. 31, No. 1-3/2001, p. 407. 
rating agencies' view on a particular issue. Reliance on these sources could be described as the basis of a "second generation informational problem" or the problem itself ${ }^{11}$. As a result, investors put their faith in sources of information and to a certain extent react in accordance with the information that is supplied to them. This undoubtedly puts the information sources in a position of power.

At this juncture it must be stressed that there is a growing oligopoly in the information zone, as more and more investors rely on the same sources of information ${ }^{12}$. Although the fact that investors use the same sources may not be a problem in itself, the influence which these sources have and the way in which they wield it could raise questions about the scope of the freedom of speech and the potential for manipulation. On one of the forums, an investor taking part in a discussion is reported to have said: "but at least newspaper X can predict trends". Reading such a remark, however, the reflection that inevitably crosses one's mind is that it could well be that newspaper $\mathrm{X}$ actually initiates trends.

The reality is that - to a certain extent - investors want to be led by someone and want to follow the herd. At the very least, they want to know what the herd is about to do. This is because in the short term the prices of their assets are increasingly determined by what others think they should be rather than by what their value really is ${ }^{13}$. The world has entered a sphere of virtual reality in which the providers of information have gained the upper hand. This problem is not something which is very visible, as it is still in the making. However, it is bound to become steadily worse as globalization progresses ${ }^{14}$.

11 A certain kind of paradox arises, because - as the regulator increases the complexity and scope of informational obligations (as well as creating various advanced regulations and technical standards) in order to mitigate the "first generation" informational problem - more and more investors tend to rely on standardized sources, thus fueling the "second generation" problem.

12 For example: the number of readers of the most popular general economic and finance newspapers in English runs to millions.

13 G.A., Olszewska, Efektywnosí a stabilność rynków finansowych w warunkach globalizacji, Studia Ekonomiczne. Zeszyty Naukowe Wydziałowe Uniwersytetu Ekonomicznego w Katowicach, Vol. 122/2012, p. 185.

${ }^{14}$ Globalization leads to the emergence of one global financial market which is somewhat disengaged from the underlying economies of individual countries. This alienation from the real economy can be seen from the perspective of time: globalization and the development of international trading have led to the globalization of financial markets and the development of international flows of money. Movements of goods and services have in turn given rise to corresponding movements and flows of money. Over time, however, with the develop- 
Globalization also has one other important dimension, namely that of information. As the geographic distance of investments increases, investors become more and more reliant on those sources of information about the market which are provided by journals, news agencies and rating agencies. Another point that can be made here is that the globalization phenomenon strongly influences the information business. As investors can have their investments in different markets, they tend to consult a source that covers all the zones. The high economic cost involved in managing information in different parts of the world can only be borne by strong global entities. A newspaper covering only part of the market cannot meet the demands of global investors and thus cannot compete with bigger providers of information. This reinforces the tendency towards the formation of an oligopoly of information sources on the market. It must also be pointed out that these entities are (generally) privately owned. In their actions and decisions, public (social) interests are therefore not a decisive factor (if indeed they are given any consideration at all).

Moreover, this problem overlaps with other issues of the financial sphere. M. Czerwonka and M. Oleśniewicz have described various problems of the financial markets and deficiencies in the strategies of investors ${ }^{15}$. Of the various kinds of behaviour which can lead to financial turbulence, a particularly important phenomenon is that of herd behaviour, meaning the rational or irrational following of the example of a group of investors. Another important phenomenon is that of noise traders, who instead of relying on fundamental data and analysis are driven to invest by factors such as sentiment or informational noise associated with a particular area or project. Yet another problem is the complex nature of financial instruments: many investors purchase these without knowing what they are purchasing. A fourth problem is that of risk insurance, the popularity of which causes investors to throw caution to the winds in the belief that they will not incur any loss whatever happens.

All these types of behaviour are connected with the second-generation informational problem and - taken together - make the system more vulnerable as a whole. As the market becomes more and more global, the size of a herd may become extremely (and, one could argue, even dangerously)

ment of enormous and diverse financial markets, we have slowly but surely arrived at a point where the flow of money and movements of money can become a priori indices that influence the value of goods. In other words, the international financial market has to some extent begun to live a life of its own. Speculation, derivatives and insurance against risks have added an extra dimension to the market.

${ }_{15}$ M. Czerwonka, M. Oleśniewicz, Racjonalność zjawiska zachowań stadnych wśród inwestorów indywidualnych, Studia i Prace Kolegium Zarządzania i Finansów, Vol. 128/2013, pp. 85-86. 
large, as the effects of the influence exerted by various sources of information could be quite severe. The potential incentives to exert influence on noise traders are easy to imagine. Moreover — slowly but surely - practically all investors would eventually become noise traders, as the complexity of financial products - coupled with the calming effect of risk insurance - would encourage investors to rely even more heavily on the "expertise" of journals and other sources, treating them as a first (and sometimes last) step towards obtaining the minimum amount of information that is needed to come to a decision.

At this juncture we must recall the fact that the main conflict which exists in the financial markets is that between private interests on the one hand and social interests on the other ${ }^{16}$. What happens at present is that there is a slow but steady shift of power from the State to private entities ${ }^{17}$. In the crucial sphere of the financial markets, such a state of affairs is hardly to be commended.

\section{THE LEGAL ANSWER}

This review of the factual circumstances should lead us to ask whether and how law could be used to regulate such a world of virtual reality. An important consideration is that globalized financial markets are very difficult or even impossible to regulate ${ }^{18}$. The means that might enable a single State (or even group of States) to influence the behaviour of the entire globalized market are quite limited, while there is little or no possibility of influencing the behaviour of people or entities in other countries or other areas of the world ${ }^{19}$.

It is extremely difficult to solve the informational problem because no one can completely and effectively control the information that is supplied

${ }_{16}$ G.A. Olszewska, op. cit., p. 190.

17 W. Szymański W., Czy globalizacja musi by irracjonalna?, Oficyna Wydawnicza SGH, Warszawa 2007, p. 21.

18 J.J. Wajszczuk, Regulatorzy wobec globalizacji rynków finansowych, „Bank i Kredyt”, Vol. 33, No. 4/2001, p. 31.

${ }_{19}$ On seeking a more globally united approach to financial law and regulations see: R.B. Thompson, Financial Regulation's Architecture within International Economic Law, "Journal of International Economic Law", Vol. 17, No. 4/2014, pp. 807-822, passim. Some of these problems have been addressed by various regulators such as the European Union and its listing of rating agencies or the new European Union directive on the abuse of the markets. However, though large on a European scale, the scope of these actions is not sufficient to solve the real problems. 
to the market in order to ensure that it is correct. In our search for the most suitable way of dealing with this problem, we may begin by examining some measures which might be implemented in the financial markets ${ }^{20}$ :

One possible method of intervention would be to do what is already standard practice in the markets, i.e. to shift the obligation onto the providers of the service. In the case of investment firms, for example, this means an obligation to check the suitability of a given financial product for a given customer. The burden of proof is to some extent shifted from the shoulders of customers and placed squarely on those of professional entities. In the case of information, this would of course lead to certain limitations on the freedom of speech $^{21}$.

Yet another measure that could be taken is to create a sanction against manipulative behaviour, though in cases of this kind it is difficult to prove intent to manipulate or the actual occurrence of manipulation ${ }^{22}$. If the sanction were severe enough, it would be very unlikely that the punished entity would be able to compensate for losses incurred, although it is also the case that sanctions could be avoided by moving elsewhere.

Another possibility would be to create a trustworthy public entity that would provide information for the market $^{23}$. Efforts could also be made to maintain the widest possible range of informational sources by creating rules to hinder the growth of the present oligopoly and providing incentives for smaller providers of information.

Given that the influence of sources of information depends on the trust which investors place in them, one possible solution would be to rate the information which is provided. In this way, the regulator would be able to eliminate or limit the influence of undesirable sources of information. This would also be proof against the "cross-border problem", because in this case globalization and the ease of access to ratings of sources would work in the favour of the regulator, thus effectively countering unreliable information. In order

${ }^{20}$ See also: J. Glanc, P. Osiewacz, Globalizacja rynków finansowych a zachowania "stadne” inwestorów, czyli jak ochronić inwestora przed samym soba, a system przed inwestorem, Kortowski Przegląd Prawniczy, No. 3/2015.

21 The sources would have to consider the effect of information ex ante and in general.

${ }^{22}$ N. Dorn, Reconstructing 'conflict of interest' in financial markets: Private management, public challenges, future prospects, "International Journal of Law, Crime and Justice", Vol. 39, No. 3/2011, p. 162.

${ }^{23}$ In case of rating agencies such proposition has been put forward, e.g. S. Schroeder, A Template for a Public Credit Rating Agency, "Journal of Economic Issues", Vol. XLVI, No. 2/2013, pp. 343-350. 
to uphold their status and credibility, the sources would have an incentive to keep in line with the standards and rules imposed by the regulator.

\section{CONCLUSIONS}

The worrying thing is not so much the lack of legal responses as the fact that there is no questioning of the acceptability of the present situation. People easily accustom themselves to new circumstances - new technologies, the existence of complex financial instruments, the global range of investment possibilities and the accessibility of information, to name but a few. In some measure, the legitimacy of the degree of reliance on information from private sources also goes unquestioned. In the long term, however, these new social and economic phenomena could pose tremendous problems.

The situation which is developing may be described as being parallel to that of market dominance in competition law, notwithstanding the fact that - unlike cases in competition law - market position abuse on the part of suppliers of information can affect the whole market, while there is no institution that can effectively penalize infringements in this zone.

Given that the informational problem is not an isolated issue but is linked to other problems of the market, the search for legal solutions is all the more justified. Greater and more extensive control over the information that is being provided to investors is crucial for the maintenance of financial stability.

\section{BIBLIOGRAPHY}

Casarin R., Squazzoni F., Being on the Field When the Game Is Still Under Way. The Financial Press and Stock Markets in Times of Crisis, "PLoS ONE", Vol. 8, No. 7/2013, http://dx.doi.org/10.1371/journal.pone.0067721.

Czerwonka M., Oleśniewicz M., Racjonalność zjawiska zachowań stadnych wśród inwestorów indywidualnych, Studia i Prace Kolegium Zarządzania i Finansów, Vol. 128/2013.

Dorn N., Reconstructing 'conflict of interest' in financial markets: Private management, public challenges, future prospects, "International Journal of Law, Crime and Justice”, Vol. 39, No. 3/2011, http://dx.doi.org/10.1016/j.ijlcj.2011.05.004.

Glanc J., Osiewacz P., Globalizacja rynków finansowych a zachowania „stadne” inwestorów, czyli jak ochronić inwestora przed samym soba, a system przed inwestorem, Kortowski Przegląd Prawniczy, No. 3/2015.

Grzelak A., Wybrane zagadnienia obecnego kryzysu ekonomicznego, Prace Naukowe Uniwersytetu Ekonomicznego we Wrocławiu. Ekonomia, Vol. 113/2010. 
Healy P.M., Palepu K.G., Information asymmetry, corporate disclosure, and the capital markets: A review of the empirical disclosure literature, "Journal of Accounting and Economics", Vol. 31, No. 1-3/2001, http://dx.doi.org/10.1016/s01654101(01)00018-0.

Kleinnijenhuis J., Schultz F., Oegema D., van Atteveldt W., Financial news and market panics in the age of high-frequency sentiment trading algorithms, "Journalism", Vol. 14, No. 2/2013, http://dx.doi.org/10.1177/1464884912468375.

Olszewska G.A., Efektywność a stabilność rynków finansowych w warunkach globalizacji, Studia Ekonomiczne. Zeszyty Naukowe Wydziałowe Uniwersytetu Ekonomicznego w Katowicach, Vol. 122/2012.

Schroeder S., A Template for a Public Credit Rating Agency, "Journal Of Economic Issues", Vol. XLVI, No. 2/2013, http://dx.doi.org/10.2753/jei0021-3624470206.

Szymański W., Czy globalizacja musi by irracjonalna?, Oficyna Wydawnicza SGH, Warszawa 2007.

Thompson P.A., Market Manipulation? Applying the Propaganda Model to Financial Media Reporting, "Westminster Papers in Communication and Culture", Vol. 6, No. 2/2009.

Thompson P.A., Invested interests? Reflexivity, representation and reporting in financial markets, "Journalism", Vol. 14, No. 2/2013, http://dx.doi. org/10.1177/1464884912474201.

Thompson R.B., Financial Regulation's Architecture within International Economic Law, "Journal of International Economic Law", Vol. 17, No. 4/2014, http://dx.doi. org/10.1093/jiel/jgu044.

Wajszczuk J.J., Regulatorzy wobec globalizacji rynków finansowych, „Bank i Kredyt”, Vol. 33, No. 4/2001. 